УдК 616.33-072.1-089.87

DOI 10.11603/2414-4533.2019.1.9918

СМ. М. ГАЛЕЙ, І. О. БАБІН, І. П. МАРЧУК

Волинська обласна клінічна лікарня

\title{
Перший досвід виконання лапароскопічної резекції шлунка за методикою Бі.льрот-ІІ з модифікацією Гофмейстера-Фінстерера
}

Мета роботи: у статті розглянуто використання малоінвазивних технологій в абдомінальній хірургії.

Ключові слова: лапароскопія; хірургія; резекція; шлунок; Більрот.

Рак шлунка - доволі поширена онкологічна патологія серед дорослого населення. Кожне п’яте вперше діагностоване онкологічне захворювання - це рак шлунка, а внаслідок чого помирає кожен третій хворий $[1,4]$. Рак шлунка виявляють від 0,3 \% у населення європейських країнах, до 1,7 \% у США. Передумовами до виникнення раку шлунка слугують запальні захворювання, хронічні інфекції, подразнювальна їжа/напої, куріння, високі дози, чи тривалий курс інгібіторів протонної помпи. Провідну роль в етіології займає Helicobacter pylori, до 60 \% усіх хворих на рак шлунка [2, 3, 5]. Поліпоз шлунка може бути наслідком інфекції, гіперпластичні поліпи можуть перероджуватись у злоякісні, хоча ймовірність цього невелика. Надаємо клінічний випадок спостереження і лікування хворого з поліпозом шлунка, якому виконали резекцію шлунка через високий ризик.

Опис клінічного випадку

Хворий Ц., 65 років, перебував на стаціонарному лікуванні у відділенні інвазивних методів діагностики та лікування Волинської обласної клінічної лікарні. При госпіталізації скаржився на загальну слабість, печію, біль у правому підребер’ї та епігастрії. 26.12.2018 р. госпіталізований у Нововолинську ЦМЛ у хірургічне відділення. При обстеженні в умовах НЦМЛ встановлено клінічний діагноз - хронічний калькульозний холецистит, стадія загострення. Проведено консервативне лікування. Хворого скеровано до ВІМДЛ для подальшого уточнення діагнозу й визначення тактики лікування. При госпіталізації - стан пацієнта середньої тяжкості, дихання везикулярне, у всіх відділах, ЧДР-15/хв, серцева діяльність ритмічна, пульс 64 уд./хв, ЧСС - 64/хв, АТ 130/70 мм рт. ст., живіт м'який, чутливий у правому підребер'ї, з піком болючості в точці Кера, епігастрії. Периферичних набряків не виявлено. При обстеженні: ЕКГ ритм синусовий, ЧСС 69/хв. При обстеженні хво- рого в умовах ВОКЛ на УЗД ОЧП було виявлено велику кількість гіперехогенних включень 5-7 мм у діаметрі, потовщення стінок більше 3 мм, при ФГДС - у верхній третині тіла шлунка з боку передньої стінки, в тілі шлунка з боку великої кривизни та передньої стінки гіперпластичні розростання слизової до 20-30 мм в діаметрі; взято біоптат. Результати гістологічного аналізу: поліпоз шлунка з тяжкою дисплазією епітелію в проліферуючих аденоматозних поліпах. Загальний аналіз крові, загальний аналіз сечі та біохімічний аналіз крові без патологічних змін. Коагулограма: ПІ 100 \%, МНВ 1,0 од., фібриноген 3,78 г/л, група крові A(II), $\mathrm{Rh}^{+}$.

Діагноз: поліпоз шлунка; хронічний калькульозний холецистит.

Виконано операційне лікування.

Протокол операції.

Після хірургічної обробки операційного поля виконано доступ за Хассеном. Створено пневмоперитонеум 14 мм рт. ст., введено лапароскоп і маніпулятори. При лапароскопії: тонкий та товстий кишечник візуально не змінені, печінка візуально не змінена. Виділено жовчний міхур, міхурову протоку й артерію, кліповано та пересічено. Холецистектомія від шийки. Шлунок мобілізовано по великій кривизні, шлунково-ободову зв'язку, шлунково-селезінкову, шлунково-діафрагмальну. У сальниковій сумці випіт відсутній, підшлункова залоза візуально незмінена. По малій кривизні розсічено шлунково-печінкову зв'язку. Під воротарем накладено степлерний шов на ДПК за допомогою EndoGIA. Виконано резекцію 2/3 шлунка за допомогою степлерного шва зі сторони малої кривизни (рис. 1, 2). Тонку кишку проведено через вікно у великому сальнику. Накладено анастомоз за Гофмейстером-Фінстерером. Виконано верхню серединну лапаротомію. Резектований шлунок виведено в рану і вилучено з черевної порожнини. Простір під анастомозом дреновано 


\section{ПОВІДОМЛЕННЯ}

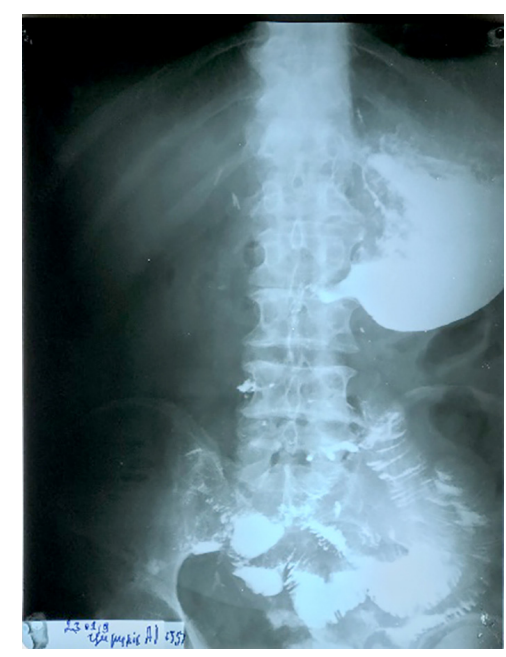

Рис. 1. Рентгеноконтрастне дослідження.

двома гумовими трубка через контрапертуру в лівому підребер'ї, ложе жовчного міхура дреновано ПВХ-трубкою через порт. Контроль на гемостаз сухо. Пошарові шви на рану.

На першу добу після операції відійшли гази, пацієнт самостійно підвівся з ліжка, переведений на ентеральне харчування. Післяопераційний період без ускладнень, суб'єктивно пацієт вказує на значне покращення стану. Клініко-лабараторно без патологічних змін. На 8-му добу після госпіталізації дані хворого виписали зі стаціонару з ре-

\section{СПИСОК ЛІТЕРАТУРИ}

1. Савельев В. С. Хирургические болезни : учеб. : в 2 т. / В. С. Савельев, Н. А. Кузнецов. - Москва, 2006. - Т. 1. - 608 с. : ил. 2. Хирургические болезни : учеб. / М. И. Кузин, Н. М. Кузин, О. С. Шкроб и др. ; под редакцией М. И. Кузина. - 3 изд. перераб. и доп. - М. : Медицина, 2002. - 784 с. : ил.

3. Хирургические болезни: учеб. / под редакцией А. Ф. Черноусова. - М. : ГЭОТАР-МЕДИА, 2010. - 664 с. : ил. + СD

\section{REFERENCES}

1. Savelyev, V.S., \& Kuznetsov, N.A. (2006). Khirurgicheskiye bolezni. Tom 1 [Surgical diseases. Vol. 1]. Moscow [in Russian]. 2. Kuzin, M.I., Kuzin, N.M., \& Shkrob, O.S. (2002). Khirurgicheskiye bolezni [Surgical diseases]. Kuzin, M.I. (Ed.). Moscow: Meditsyna [in Russian].

3. Chernousov, A.F. (2010). Khirurgicheskye bolezni: uchebnik [Surgical diseases: textbook]. Moscow: GEOTAR-MEDIA [in Russian].

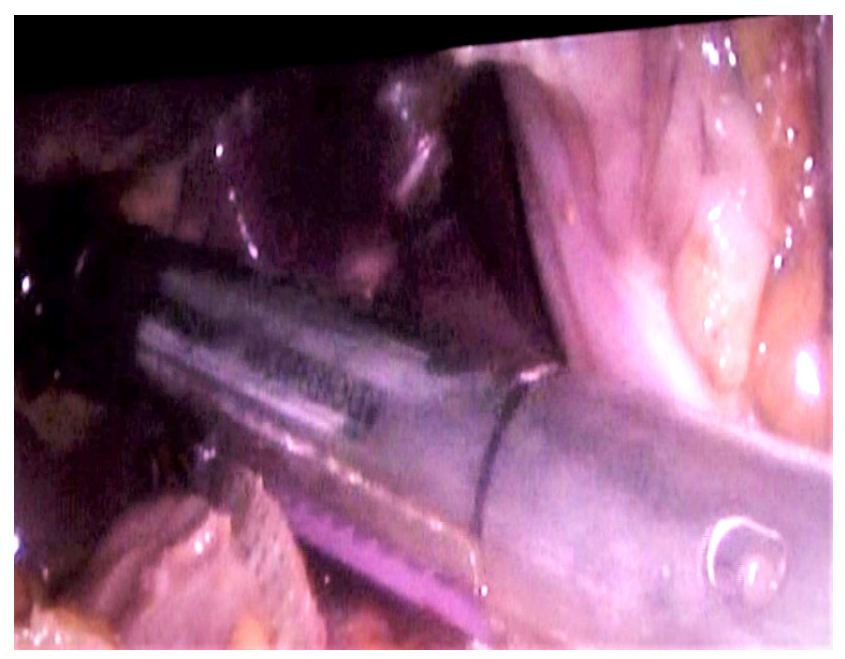

Рис. 2. Накладання степлерного шва.

комендаціями щодо доби і повторного огляду через 4 тижні.

Лапароскопічні технології допомагають швидко і максимально комфортно для пацієнта виконувати навіть складні операційні втручання. Поєднання таких технологій, як лапароскопія та ендоскопія дозволяють в режимі реального часу відразу в операційній корегувати хід операції, для досягнення ефективного операційного лікування з максимальним збереженням здорових тканин пацієнта.

4. Харнас С. С. Рак желудка (клиника, диагностика, лечение) : учеб. пособ. / С. С. Харнас В. В. Левкин, Г. Х. Мусаев. - М., 2006. -84 с.

5. Курс лекций по патологической анатомии. Частный курс. Часть I. Часть II, книги 1, 2 / Под ред. академика РАН и РАМН, профессора М. А. Пальцева. - М. : ООО “Издательский дом “Русский врач”, 2003. - 210 с.

4. Kharnas, S.S., Levkin, V.V., \& Musayev, G.Kh. Rak zheludka: klinika, diagnostika, lechenye [Stomach cancer: clinic, diagnosis, treatment]. [in Russian].

5. Paltsev, M.A. (Ed.). (2003). Kurs lektsyy po patologicheskoy anatomii. Chastnyy kurs. Chast II, knigy 1,2. [Course of lectures on pathological anatomy. Private course. Part II, book 1, 2]. Moscow: OOO „Izdatelskyy dom „Russkiy vrach” [in Russian].

Отримано 31.01.2019 
M. M. HALEY, I. O. BABIN, I. P. MARCHUK

Volyn Regional Clinical Hospital

FIRST EXPERIENCE OF PERFORMING LAPAROSCOPIC HOFMEISTER-FINSTERER PARTIAL GASTRECTOMY

The aim of the work: to claim a possibility of using mini-invasive technology in abdominal surgery.

Key words: laparoscopy; surgery; resction; stomach; Bilrot.

Н. М. ГАЛЕЙ, И. О. БАБИН, И. П. МАРЧУК

Волынская областная клиническая больница

ПЕРВЫЙ ОПЫТ ПРОВЕДЕНИЯ ЛАПАРОСКОПИЧЕСКОЙ РЕЗЕКЦИИ ЖЕЛУДКА ПО МЕТОДИКЕ БИЛЬРОТ-ІІ В МОДИФИКАЦИИ ГОФМЕЙСТЕРА-ФИНСТЕРЕРА

Цель работы: в статье рассмотрена возможность использования малоинвазивных методов в абдоминальной хирургии.

Ключевые слова: лапароскопия; хирургия; резекция, желудок; Бильрот. 